\title{
Effects of sesame meal on intake, digestibility, rumen characteristics, chewing activity and growth of lambs
}

\author{
B. Ghorbani, A. Teimouri Yansari" \& A. Jafari Sayyadi \\ Department of Animal Science, College of Animal Science and Aquaculture, Sari University of Agriculture and Natural \\ Resources University (SANRU), Iran
}

(Received 22 March 2016; Accepted 18 June 2017; First published online 30 November 2017)

\author{
Copyright resides with the authors in terms of the Creative Commons Attribution 4.0 South African License. \\ See: http://creativecommons.org/licenses/by/4.0/za \\ Condition of use: The user may copy, distribute, transmit and adapt the work, but must recognize the authors and the South \\ African Journal of Animal Science.
}

\begin{abstract}
Two experiments were carried out to determine ruminal degradability of sesame meal (SSM) and its effects on intake, digestibility, rumen parameters, chewing activity, and lamb performance when it replaced soybean meal (SBM). Degradability of dry matter (DM) and crude protein (CP) were determined with the nylon bag technique using three fistulated Zel ewes. The quickly and potentially degradable DM of SSM was lower, but their degradation rates of DM were similar. The quickly degradable protein in the SSM was greater, but the slowly degradable protein of SSM was lower. Potential degradable protein of SBM was greater. The degradation rate of protein was greater in the SSM. Thirty Zel lambs were assigned to five treatments, namely 1) control diet that contained SBM, and 2), 3), 4) and 5) diets that contained 25, 50, 75 , and $100 \%$ DM of SSM partially or entirely replacing SBM and part of barley grain. There was no difference in the intakes of DM, CP, ether extract (EE), and non-fibre carbohydrate (NFC) among treatments, but neutral detergent fibre (NDF) intake increased when the SSM inclusion rate was increased. Digestibility of DM and $\mathrm{EE}$, passage rate, and total mean retention time differed, but the digestibility of NDF, CP, and NFC, rumen liquid $\mathrm{pH}$ and $\mathrm{NH}_{3}-\mathrm{N}$, passage rate, rumen retention time, eating time, rumination, total chewing activity, DM intake, daily gain, feed conversation ratio, carcass yield and characteristics were not different between treatments. Replacing the SBM with SSM in lamb, improved intake, digestibility, and rumen condition, without reduction in performance and carcass composition.
\end{abstract}

Keywords: Carcass characteristic, feedlotting, lamb, mean retention time, ruminal degradability, soybean meal

\#Corresponding author: astymori@yahoo.com

\section{Introduction}

Sheep feed costs represent almost $65 \%$ to $70 \%$ of intensive production system input. Attempts have been made to reduce feed costs by using cheaper alternative sources of protein and energy. Therefore, it is essential to incorporate cheap local materials in animal feeds from agricultural and industrial processing. Sesame meal (SSM) is a relatively good protein source that can be used in ruminants without any harmful effects to improve dry matter intake (DMI) and CP, fibre and EE digestibility (Khan et al., 1998; Obeidat \& Gharaybeh, 2011). However, sesame seed has high amounts of oxalate and phytic acid, which reduces the bioavailability of its calcium, but dehulling reduces its oxalic acid contents (FAO, 1990). Additional advantages are that sesame seed contains about $50 \%$ oil and $20-25 \%$ CP (Obeidat et al., 2009). Therefore, it can be used as a protein supplement to replace traditional sources such as SBM in feeding sheep to help reduce feed cost.

Few studies have evaluated the effect of using SSM to feed sheep (Omar, 2002; Obeidat et al., 2009; Obeidat \& Aloqaily, 2010; Hassan et al., 2013). Omar (2002) reported that the inclusion of the SSM at $10 \%$ and $20 \%$ improved digestibility of protein and fibre, average daily gain (ADG), feed conversion ratio (FCR), and the ratio of the cost of feed to gain $(\mathrm{kg})$ in growing Awassi lambs. Obeidat et al. (2009) found that when SBM was replaced with SSM (with $46 \%$ CP), finishing performance improved, and cost of production diminished, without detrimental effects to carcass characteristics or meat quality of Awassi lambs. Also, Obeidat \& Aloqaily (2010) found that when SBM and barley grain were replaced by sesame hull at levels of 
$12.5 \%$ and $25 \%$, the finishing performance of Awassi lambs was improved and the cost of production was reduced. Pollot et al. (1978) found that Sudan Desert male and female lambs fed on rations containing $40 \%$ sesame cake achieved growth rates of 150 and $106 \mathrm{~g} /$ day, respectively. In addition, Obeidat \& Gharaybeh (2011) reported that replacing barley and SBM with sesame hull in finishing diets of Black goat kids improved nutrient intake and ADG, and reduced cost of gain. Hassan et al. (2013) found that the addition of the sesame cake up to $20 \%$ led to satisfactory feedlot performance, and improved carcass yield in comparison with groundnut cake. However, little attention has been paid to ruminal degradability and use of SSM in sheep feeding. Therefore, the objective of this study was to determine ruminal degradability parameters of DM and CP of SSM, and to evaluate the effect of replacing SBM with SSM on feed intake, nutrient digestibility, ADG, carcass characteristics, and meat quality of growing Zel lambs.

\section{Material and methods}

In the first experiment, the rumen degradation of DM and protein for SBM and SSM was determined with the in situ method, using three fistulated Zel ewes (approximately two years old, average bodyweight (BW) $30 \pm 2 \mathrm{~kg}$ ). Each sheep had access to clean drinking water ad libitum and was housed in $1 \mathrm{~m} \times 1.5 \mathrm{~m}$ individual pens in a shed. The sheep were fed at maintenance level with diets contained 80.0, 10.0, 3.0, 2.0, $2.0,2.0$, and $0.1 \%$ of DM corn silage, ground barley, cottonseed meal, wheat bran, beet pulp, rice straw, and mineral and vitamin supplement, respectively. Four bags of $3 \mathrm{~g}$ of DM of test SBM or SSM were weighed in nylon bags $(6 \mathrm{~cm} \times 7.5 \mathrm{~cm}$, polyamide, $26 \%$ porosity $40 \pm 10 \mu$ pore size), which were closed with a heat sealer, and incubated in the rumen for each of the following periods, namely $0,1,3,6,12,24,36,48,72$, and 96 hours. However, the 0 hour bags were not incubated, but left and processed with the rest of the bags at the end of all incubations. All incubations started after feeding in the morning. Bags were attached to a plastic tube (5-mm diameter), which was fixed to the outside of the fistula with a string. The bags and the tubes had free movement inside the rumen and reticulum. On removal, bags were washed in cold water until the effluent ran clear. The bags were dried in an oven at $55^{\circ} \mathrm{C}$ for 48 hours, and weighed. Following the weighing, bags were opened, and residues from the four bags for each period were homogenized and placed in tightly capped plastic bottles. Samples were analysed for DM, organic matter (OM), Kjeldahl nitrogen (AOAC, 2000), and NDF (Van Soest et al., 2001). The nitrogen fractions, defined according to the Cornell net carbohydrate and protein system (CNCPS), were determined using the methods described by Licitra et al. (1996). All analyses were made on combined residues of the four bags. The analyses were run in duplicate and rerun separately when differences were greater than $3 \%$ and sufficient residue was available. The potentially degradable fraction was calculated as 100 minus the 0 -h fraction.

Kinetics of DM, CP, and NDF disappearance in situ were estimated by the nonlinear regression procedure of SAS (2005). For each sample, the following model was fitted to the percentage of disappearance of DM, CP, and NDF (Ørskov \& McDonald, 1979):

$$
\mathrm{Y}=a+b\left(1-\exp ^{\left(\mathrm{K}_{\mathrm{d}}^{\mathrm{T}}\right)}\right)
$$

Where: $a=$ soluble fraction (\%)

$$
\begin{aligned}
& b=\text { slowly digestible fraction }(\%) \\
& \mathrm{K}_{\mathrm{d}}=\text { fractional rate of disappearance }(\% / \mathrm{h}) \\
& \mathrm{T},=\text { time of incubation }(\mathrm{h})
\end{aligned}
$$

The equation $E D=\left[a+b \times K_{d} /\left(K_{d}+K_{p}\right)\right]$ was used to calculate effective degradability (ED). In this equation, $\mathrm{K}_{\mathrm{p}}$ represents the rumen flow rate of particles, which theoretically were considered equal to 0.02 (maintenance level), 0.04 and $0.06 \% / h$ (Table 1).

This experiment was designed as a complete randomized design with SBM and SSM as two treatments with four replications in each sheep. Data of the constants were analysed with the GLM procedure of $S A S^{\circledR}$ (2005). Means were separated using Duncan's multiple range tests with an alpha level of 0.05 . 
Table 1 Ruminal dry matter degradability, and effective degradability of sesame and soybean meal after incubation in the rumen of Zel ewes with ruminal cannula using the nylon bag technique

\begin{tabular}{|c|c|c|c|c|}
\hline Digestion parameters $^{1}$ & Sesame meal & Soybean meal & SEM & $P$-value \\
\hline \multicolumn{5}{|l|}{ Dry matter } \\
\hline$a(\%)^{2}$ & $19.23^{b}$ & $26.61^{\mathrm{a}}$ & 0.0118 & 0.0114 \\
\hline$b(\%)^{3}$ & 64.14 & 68.35 & 0.0203 & 0.2161 \\
\hline$(a+b)(\%)^{4}$ & $83.37^{b}$ & $94.96^{\mathrm{a}}$ & 0.0271 & 0.0391 \\
\hline$C(\%)^{5}$ & $16.63^{\mathrm{a}}$ & $5.04^{\mathrm{b}}$ & 0.0271 & 0.0391 \\
\hline$K_{d}(\% / h)^{6}$ & 3.43 & 3.37 & 0.0056 & 0.9475 \\
\hline \multicolumn{5}{|c|}{ Effective degradability on different $K_{p}(\% / h)^{7}$} \\
\hline 0.02 & $58.69^{b}$ & $69.37^{\mathrm{a}}$ & 0.007 & 0.0004 \\
\hline 0.04 & $47.93^{b}$ & $57.77^{\mathrm{a}}$ & 0.0091 & 0.0016 \\
\hline 0.06 & $41.84^{b}$ & $51.13^{\mathrm{a}}$ & 0.0089 & 0.0018 \\
\hline \multicolumn{5}{|l|}{ Crude protein } \\
\hline$a(\%)$ & $13.85^{\mathrm{a}}$ & $10.79^{b}$ & 0.0042 & 0.0065 \\
\hline$b(\%)$ & $53.34^{b}$ & $80.00^{\mathrm{a}}$ & 0.0204 & 0.0008 \\
\hline$(a+b)(\%)$ & $67.19^{b}$ & $90.79^{\mathrm{a}}$ & 0.0212 & 0.0014 \\
\hline C (\%) & $32.8^{\mathrm{a}}$ & $9.21^{b}$ & 0.0014 & 0.0014 \\
\hline$K_{d}(\% / h)$ & $3.68^{\mathrm{a}}$ & $3.29^{\mathrm{b}}$ & 0.0015 & 0.0346 \\
\hline \multicolumn{5}{|c|}{ Effective degradability on different $K_{\mathrm{P}}(\% / \mathrm{h})$} \\
\hline 0.02 & $48.42^{b}$ & $60.54^{\mathrm{a}}$ & 0.0031 & $<0.0001$ \\
\hline 0.04 & $39.42^{b}$ & $46.89^{\mathrm{a}}$ & 0 & $<0.0001$ \\
\hline 0.06 & $34.14^{b}$ & $39.12^{\mathrm{a}}$ & 0.0018 & 0.0003 \\
\hline
\end{tabular}

$\overline{a, b}$ Row means with different superscripts differ significantly at $P<0.05$

${ }^{1}$ For each sample, the model $\left.\mathrm{D}=a+b\left(1-\exp ^{\left(-k_{d}^{T}\right.}\right)\right)$ was fitted to the percentage of disappearance of DM. Where, a, soluble fraction $(\%) ; b$, slowly digestible fraction $(\%) ; k_{d}$, fractional rate of disappearance $(\% / h)$, and $\mathrm{T}$, time of incubation $(0,1,3$, $6,12,24,36,48,72$ and 96 h) (Ørskov \& McDonald, 1979)

${ }^{2}$ Soluble fraction $(\%)$

${ }^{3}$ Slowly digestible fraction (\%)

${ }^{4}$ Potential extent of degradation $(a+b)$

${ }^{5}$ Undegradable fraction calculated as $C=100-(a+b)(\%)$

${ }^{6} \mathrm{Fractional}$ rate of disappearance $(\% / \mathrm{h})$

${ }^{7}$ The equation $\mathrm{ED}=\left[a+b \times \mathrm{Kd} /\left(\mathrm{K}_{\mathrm{d}}+K_{\mathrm{P}}\right)\right]$ was used to calculate effective degradability (ED). In this equation, $K_{\mathrm{P}}$ represents the flow rate of particles out of the rumen that was considered equal to $0.02,0.05$, and 0.06

In the second experiment, the study was carried out at the Ruminant Research Center of Sari Agricultural and Natural Resources University (SANRU), Iran. The SANRU Institutional Animal Care and Use Committee approved all procedures used in this study. Thirty Zel lambs were assigned randomly to 1 of 5 experimental diets, namely i) control diet, which contained $11.14 \%$ SBM as protein sources of the DM, and ii), iii), iv, and v) diets that contained $25,50,75$, and $100 \%$ SSM to replace SBM and part of barley grain (Table 2). At the start of the experiment, lambs were weighed, ear tagged, dipped, treated against internal and external parasites, housed in individually shaded pens $(0.80 \mathrm{~m} \times 1.55 \mathrm{~m})$, and fed twice daily at $08 \mathrm{~h} 00$ and $20 \mathrm{~h} 00$ for 90 days. The first week was an adaptation period to allow animals to acclimatize prior to the start of the experiment. All diets were formulated to meet the requirements for fattening male lambs according to NRC (2007) using SRNS ${ }^{\circledR}$ software. SSM was obtained from a local oil extraction industry company, which extracted oil mechanically. 
Table 2 Ingredients, chemical compositions, intake and nutrients digestibility ${ }^{1}$ in lambs fed experimental rations that contained various soybean meal/sesame meal ratios

\begin{tabular}{|c|c|c|c|c|c|c|c|}
\hline Items & $\begin{array}{c}\text { Treatment } 1 \\
\text { (Control) }\end{array}$ & $\begin{array}{c}\text { Treatment } 2 \\
(75: 25)\end{array}$ & $\begin{array}{c}\text { Treatment } 3 \\
(50: 50)\end{array}$ & $\begin{array}{c}\text { Treatment } 4 \\
(25: 75)\end{array}$ & $\begin{array}{c}\text { Treatment } 5 \\
(0: 100)\end{array}$ & SEM & $P$-Value \\
\hline \multicolumn{8}{|c|}{ Ingredients (\% of DM) } \\
\hline Soy bean meal & 11.14 & 8.10 & 5.42 & 2.68 & 0 & $\ldots$ & $\ldots$ \\
\hline Barley grain & 50.28 & 50.61 & 50.61 & 50.69 & 50.69 & $\ldots$ & $\ldots$ \\
\hline Sesame meal & 0.0 & 2.59 & 5.26 & 7.87 & 10.55 & $\ldots$ & $\ldots$ \\
\hline Wheat bran & 6.44 & 6.48 & 6.49 & 6.49 & 6.49 & $\ldots$ & $\ldots$ \\
\hline Beet pulp & 13.27 & 13.36 & 13.36 & 13.38 & 13.38 & $\ldots$ & $\ldots$ \\
\hline Wheat straw & 18.23 & 18.22 & 18.22 & 18.25 & 18.25 & $\ldots$ & $\ldots$ \\
\hline $\mathrm{DCP}$ & 0.40 & 0.40 & 0.40 & 0.40 & 0.40 & $\cdots$ & $\cdots$ \\
\hline Salt & 0.24 & 0.24 & 0.24 & 0.24 & 0.24 & $\ldots$ & $\ldots$ \\
\hline \multicolumn{8}{|c|}{ Chemical compositions (\% of DM) ${ }^{1}$} \\
\hline DM & 90.82 & 91.50 & 91.08 & 91.70 & 91.66 & $\ldots$ & $\ldots$ \\
\hline NDF & 39.33 & 36.33 & 36.67 & 38.00 & 40.00 & $\cdots$ & $\ldots$ \\
\hline $\mathrm{CP}$ & 16.50 & 17.23 & 17.23 & 16.10 & 16.62 & $\ldots$ & $\ldots$ \\
\hline Ash & 5.17 & 4.00 & 4.67 & 5.33 & 4.75 & $\cdots$ & $\cdots$ \\
\hline EE & 5.00 & 5.33 & 5.66 & 6.16 & 7.00 & $\ldots$ & $\ldots$ \\
\hline NFC & 33.99 & 39.43 & 35.76 & 34.41 & 31.62 & $\ldots$ & $\ldots$ \\
\hline \multicolumn{8}{|l|}{ Intake $^{2}$ (g/day) } \\
\hline DM & 967.9 & 981.8 & 996.3 & 1060.5 & 1057.8 & 39.498 & 0.3637 \\
\hline NDF & $419.2^{c}$ & $689.8^{a}$ & $401.1^{c}$ & $439.9^{b c}$ & $561.6^{\mathrm{ab}}$ & 42.884 & 0.0035 \\
\hline $\mathrm{CP}$ & 175.8 & 184.9 & 188.5 & 186.4 & 191.8 & 13.681 & 0.9376 \\
\hline Ash & 53.29 & 57.19 & 62.0 & 71.30 & 80.78 & 11.210 & 0.4574 \\
\hline EE & 55.11 & 42.92 & 51.08 & 61.70 & 54.82 & 4.820 & 0.1650 \\
\hline NFC & 362.3 & 423.1 & 391.2 & 398.3 & 364.9 & 14.879 & 0.0796 \\
\hline \multicolumn{8}{|l|}{ Digestibility $^{1}$ (\%) } \\
\hline DM & $78.07^{b}$ & $81.83^{\mathrm{a}}$ & $81.42^{a}$ & $80.59^{a}$ & $78.56^{b}$ & 0.008 & 0.0156 \\
\hline NDF & 63.90 & 64.72 & 66.39 & 67.71 & 63.83 & 0.014 & 0.4093 \\
\hline $\mathrm{CP}$ & 79.35 & 83.43 & 82.24 & 80.79 & 81.05 & 0.012 & 0.1823 \\
\hline EE & $80.42^{b}$ & $80.44^{b}$ & $84.64^{a}$ & $85.19^{a}$ & $79.54^{b}$ & 0.011 & 0.0065 \\
\hline NFC & 97.81 & 98.05 & 98.89 & 98.01 & 97.52 & 0.005 & 0.4412 \\
\hline
\end{tabular}

\footnotetext{
a,b, c Row means with different superscripts differ significantly at $P<0.05$.

${ }^{1}$ DM, dry matter; NDF, neutral detergent fiber; CP, crude protein; EE, ether extract; and NFC, non fiber carbohydrate.

${ }^{2}$ Five experimental rations as treatments: 1) the basal diet with soybean meal as a protein source, 2), 3i), 4, and 5) the basal diets with $25,50,75$, and $100 \%$ of the soybean meal replaced with sesame meal, respectively
}

A total mixed ration was offered at ad libitum (110\% of the previous day's intake) to all animals, with free access to fresh water and mineral block throughout the experiment. Lambs were weighed at the beginning of the experiment and then bi-weekly before the morning feeding throughout the study. For each lamb, individual refusals of feed were weighed daily and stored at $-20^{\circ} \mathrm{C}$ until analysed for DM and other nutrients to evaluate daily nutrient intake. Samples of refusals collected daily from individual lambs were pooled over the entire experimental period and sub-sampled for analysis. The feeds, rations, and orts were sampled regularly and analysed for DM, OM, CP, EE, ash at $605^{\circ} \mathrm{C}$ (AOAC, 2000), NDF and ADF (Van Soest et al., 1991); with modifications for use in the ANKOM 2000 fibre analyser apparatus and using sodium sulfite and alpha amylase (heat stable). Non fibrous carbohydrate (NFC) was calculated by $100-(\mathrm{CP} \%+$ NDF\% + Ash\% + EE \%; NRC, 2007).

On day 50 of the fattening period, two animals from each treatment were selected at random and housed individually in metabolism crates $(1.05 \mathrm{~m} \times 0.80 \mathrm{~m})$ to evaluate nutrient digestibility. Animals were 
allowed a period of seven days to adapt to the metabolism crates. In the subsequent collection period of five days, feed intake and refusals were recorded and sampled (Obeidat \& Aloqaily, 2010). Daily faecal output was collected, weighed, and recorded, and then $10 \%$ was kept for subsequent analyses. Faecal samples were dried at $55^{\circ} \mathrm{C}$ in a forced-air oven to reach a constant weight, air equilibrated, and then ground to pass through a $1 \mathrm{~mm}$ screen and kept for further analysis. Diets, refusals, and faeces were analysed for DM, OM, $\mathrm{CP}, \mathrm{EE}, \mathrm{NDF}$, and ADF (as described).

At the end of the experiment, blood samples were taken from the jugular vein of each animal into vacutainers. The serum was separated by centrifugation at $750 \times g$ for $15 \mathrm{~min}$ and stored at $-20^{\circ} \mathrm{C}$ until used. The concentrations of glucose, cholesterol, triglyceride and HDL-cholestrol were measured using appropriate commercial laboratory kits (Kit \# 1050012, Parsazmun Co. Iran). The VLDL-cholesterol was estimated as one-fifth of the concentration of triglycerides.

Chromium-mordanted alfalfa NDF was used as a single dose marker to determine solid passage rate and rumen retention time (Uden et al., 1980). On day 50, markers were fed to all sheep at the morning feeding time. Faecal grab samples were taken at $0,12,18,24,36,48,60,72,96,120$, and 144 hours after dosing to determine the passage rate, rumen and total mean retention time, and time delay of the marker (Table 4). Samples were dry-ashed, and faecal chromium ( $\mathrm{Cr}$ ) concentrations were determined by direct current plasma emission spectroscopy (AOAC, 2000). Faecal $\mathrm{Cr}$ excretion curves were fitted to the double compartment model represented by two exponential constants and a time delay (Grovum \& Williams, 1973):

Where: $Y=$ marker concentration $(\mathrm{ppm})$

$$
\begin{aligned}
& Y=A e^{-k}{ }_{1}{ }^{(t-T T)}-A e^{-k}{ }_{2}{ }^{(t-T T)}, k_{1}=k_{2} \text { for } t<T \text {, } \\
& \mathrm{Y}=0 \text { for } \mathrm{t}=\mathrm{TT} \text {, }
\end{aligned}
$$

$$
\begin{aligned}
& A=\text { scale parameter } \\
& k_{1}=\text { rumen rate of passage }(\% / h) \\
& k_{2}=\text { lower digestive tract rate of passage }(\% / h) \\
& t=\text { sampling time post dosing }(h) \\
& \text { TT }=\text { transit time or time delay of the marker }(h)
\end{aligned}
$$

The total mean retention time was calculated as the sum of rumen mean retention time $\left(1 / \mathrm{k}_{1}\right)$ and, in the lower digestive tract, mean retention time $\left(1 / \mathrm{k}_{2}\right)$ plus the transit time $(\mathrm{TT})$. Data were analysed by NLIN regression using the PROC NLIN (iterative Marquardt method) procedure of SAS ${ }^{\circledR}$ (2005, Table 4). The estimated parameters were analysed according to the above experimental design.

Eating and ruminating activities were monitored for 24 hours using a regular 5-min interval observation technique by one person for all sheep in the treatments for two days from days 88 to 90 (Table 5). Total time spent chewing was calculated as the total time spent eating and ruminating (Table 5). The average DMI in the experimental period was used to estimate the time spent eating, ruminating, and total chewing activity per daily intake of DM, NDF, NFC, and BW.

Carcass yield and carcass characteristics were determined (Yardımcı et al., 2008). Feed was withheld 12 hours before slaughter, but water was provided. The slaughtering process of all lambs entails the severing of the jugular vein and the carotid arteries and removal of non-carcass organs. After slaughter, the carcasses were stored overnight at $4{ }^{\circ} \mathrm{C}$ for 24 hours and then weighed. The carcasses were split longitudinally into two equal halves. The weights of both sides were recorded. The left side was divided into six cuts (leg, shoulder, brisket, neck, back and loin), which were dissected into muscle, bone and fat (subcutaneous and intermuscular) tissue and were weighed separately (Yardımcı et al., 2008).

The experimental design consisted of a completely randomized design. Analysis of variance was conducted using the SAS ${ }^{\circledR}$ GLM procedure (SAS, 2005) by the model:

$$
Y_{i j}=\mu+\alpha_{i}+e_{i j}
$$

Where: $Y_{i j}$ is the dependent variable

$\mu$ is the overall mean

$\alpha_{i}$ is the random effect of the experimental diets ( $i=1$ and 5 )

$e_{i j}$ is random error on animal $j$ in treatment $i$

Means were separated using the Duncan multiple range test with an alpha level of 0.05 . 


\section{Results and discussion}

The SSM and SBM had $94.17 \pm 0.24,87.88 \pm 0.08,32.20 \pm 0.77,48.43 \pm 0.96,3.46 \pm 0.17$ and $3.78 \pm$ 1.29; $91.00 \pm 0.56,91.70 \pm 0.18,44.01 \pm 0.44,21.7 \pm 0.34,5.80 \pm 0.22$ and $20.19 \pm 0.96(\% \pm$ SD) of DM, OM, CP, NDF, EE and NFC, respectively. The SSM had lower CP $(P<0.0001)$ and NFC $(P<0.0001)$ content, but higher NDF $(P<0.0001)$ than SBM. The ammonia nitrogen content was 6.76 and $5.54 \%$ of $\mathrm{CP}$ in SBM and SSM, respectively. Sesame meal, cake and hull are by-products of the oil extraction industry and their chemical compositions vary depending on the varieties, seed processing method, harvesting time and extraction methods. The DM content of SSM ranges from 83 to $96 \%$, while CP, ash, ether extract, NFE, and crude fibre are $23-46,7.5-17,1.4-27,25-32$, and 5-12\%, respectively (FAO, 1990). Obeidat \& Gharaybeh (2011) reported that the CP and metabolizable energy content of sesame hulls were $25.8 \%$ and 3.92 $\mathrm{kcal} / \mathrm{kg}$, respectively. Şehu et al. (2010) found that DM, ash, CF, EE, and CP of the SSM were 94.3, 4.80, 16.0, 51.2, and $17.3 \%$, respectively. Marghazani et al. (2013) reported that SSM had 7.81 $\pm 0.37,37.84 \pm$ $0.53,7.35 \pm 0.34$, and $3.97 \pm 0.30(\% \pm \mathrm{SD})$ ash, $\mathrm{CP}, \mathrm{EE}$, and CF, respectively. The lower level CP of SSM in comparison with SBM could be attributed to its higher level of NDF and lower content of NFC. The chemical composition of sesame oil cake varies depending on the method of processing the seed, using mechanical or solvent extraction (FAO, 1990). Recently, Wang et al. (2016) reported that the concentrations of NDF, ADF, and EE were $15.94 \%$ and $30.31 \%, 6.97 \%$ and $13.97 \%$, and $1.77 \%$ and $7.55 \%$ for SBM and SSM, respectively. The neutral detergent insoluble crude protein (NDICP) values of SBM and SSM were 0.72 and $2.21 \%$, respectively. The acid detergent insoluble crude protein (ADICP) values of these sources were $0.59 \%$ and $0.86 \%$, respectively. Wang et al. (2016) found that the NDICP contents of SBM and SSM were 0.67 and $2.56 \%$, and the ADICP contents of these sources were $0.46 \%$ and $1.10 \%$, respectively. However, as a protein source, SSM has a CP content of $32.20 \pm 0.77$, which is higher than the CP contents of $30.93 \%$ reported by Solomon (1992), but lower than the $37.5 \%$ reported by Njie (1995) and the $39.92 \%$ by Fitwi \& Tadesse (2013). This may be because of the difference in efficiency of the extraction method of screw pressing (Solomon, 1992; Njie, 1995).

The in situ DM and CP disappearances values of SSM and SBM are given in Table 1. The quickly and potential degradable DM of SBM was greater than SSM. However, the slowly digestible fraction and fractional rate of disappearance of the two meals was similar $(P=0.9475)$. In addition, SSM had a higher undegradable fraction of DM in comparison with SBM. The quickly degradable, indigestible fraction and fractional rate of disappearance of CP in the SSM were greater than the SBM. The SBM had a higher potential digestible fraction than SSM. Şehu et al. (2010) found that 82.65 and $86.50 \%$ of DM and CP were degraded after 24 hours of ruminal incubation for sesame seed, respectively. The values of $a, b$ and $c$ fraction for the DM and CP of sesame seed were $27.64(\%), 60.09(\%)$, and $0.1014(\% / \mathrm{h}) ; 25.83(\%), 66.51$ $(\%)$, and $0.1001(\% / \mathrm{h})$, respectively (Şehu et al., 2010). In the present experiment, the DM and CP degradability values of the SSM reached 80.22 and $65.32 \%$ at 48 hours incubation in the rumen. However, these values of SBM reached 92.31 and $85.72 \%$ at 48 hours incubation in the rumen.

There was no significant difference in intake of DM, CP, EE and NFC among treatments, but NDF intake $(P=0.0035)$ increased with increasing SSM ratio (Table 3). This might be due to the desire by sheep in diets to meet their energy and nutrient requirement through an increase of intake of DM relative to control treatment (Fitwi \& Tadesse, 2013). Tesfay (2007) and Fitwi \& Tadesse (2013) reported that the intake of crude fibre and ADF were not significantly affected by supplementation of SSM concentrate. However, Omar (2002) reported that the intake of DM and protein reduced by $4 \%$ and $2 \%$ for lambs consuming $10 \%$ and $20 \%$ sesame cake, respectively. The CP intake among the treatments was similar, but there was an increasing trend in CP intake as the level of sesame increased, hence the highest and lowest intakes were observed in Treatment 5 and control, respectively. The increased CP intake with the higher SSM rations is due to the increased total DMI and higher CP content of the SSM in comparison with the basal diet. Obeidat et al. (2009) found that Awassi lambs on diets containing 25\% sesame hull had improved feed intake, except for $\mathrm{CP}$, and that this improvement might be attributed in part to higher palatability and lower dustiness in the diet as a result of higher EE, which trapped dust particles. Similar effects on intake were reported when Awassi lambs were fed with $8 \%$ of DM of SSM in sheep diet (Obeidat et al., 2009). Consistent with the results reported in the current study, Khan et al. (1998) observed that using SSM containing CP of $32.06 \%$ in feeding growing bull calves increased their intake. On the contrary, Omar (2002) reported that DMI decreased, though not significantly, when $10 \%$ and $20 \%$ of SSM were incorporated into Awassi lamb diets, but fat intake increased. However, Omar et al. (2002) reported that $10 \%$ and $20 \%$ of the SSM in lamb diets improved digestibility of $\mathrm{CP}$ and fibre, ADG, FCR, and reduced the cost of feed per gain in growing Awassi lambs. 
Table 3 Dry matter intake, daily gain, and feed conversation in lambs fed experimental rations that contained different soybean $\mathrm{meal} / \mathrm{sesame}$ meal ratios

\begin{tabular}{|c|c|c|c|c|c|c|c|}
\hline Items & $\begin{array}{c}\text { Treatment } 1 \\
\text { (Control) }\end{array}$ & $\begin{array}{c}\text { Treatment } 2 \\
(25: 75)\end{array}$ & $\begin{array}{c}\text { Treatment } \\
3(50: 50)\end{array}$ & $\begin{array}{l}\text { Treatment } \\
4(25: 75)\end{array}$ & $\begin{array}{c}\text { Treatment } \\
5(0: 100)\end{array}$ & SEM & $P$-value \\
\hline \multicolumn{8}{|c|}{ Dry matter intake (g/day) } \\
\hline $1-15$ & 1222.5 & 1180.8 & 1196.7 & 1204.2 & 1214.2 & 33.96 & 0.3748 \\
\hline $16-30$ & 1187.5 & 1213.33 & 1283.2 & 1306.0 & 1337.5 & 56.71 & 0.3354 \\
\hline $31-45$ & 1308.5 & 1389.2 & 1318.3 & 1380.0 & 1417.5 & 73.22 & 0.7949 \\
\hline $46-60$ & 1302.2 & 1363.3 & 1293.3 & 1457.5 & 1425.0 & 89.54 & 0.6287 \\
\hline $61-75$ & 1474.0 & 1291.7 & 1470.8 & 1597.5 & 1530.0 & 101.26 & 0.3291 \\
\hline 76-90 & 1474.0 & 1276.7 & 1516.7 & 1620.8 & 1505.0 & 99.27 & 0.2251 \\
\hline Total period & 1065.8 & 1073.1 & 1093.9 & 1157.5 & 1154.0 & 55.25 & 0.6445 \\
\hline \multicolumn{8}{|c|}{ Daily gain of lambs (g/day) } \\
\hline 1 to 15 & 205.0 & 183.3 & 293.3 & 291.7 & 241.7 & 40.508 & 0.2494 \\
\hline $16-30$ & 178.3 & 166.7 & 173.3 & 191.7 & 175.0 & 31.153 & 0.9849 \\
\hline $31-45$ & 161.7 & 190.0 & 177.5 & 239.2 & 167.5 & 22.674 & 0.0604 \\
\hline $46-60$ & 171.7 & 163.3 & 233.3 & 250.0 & 233.3 & 27.227 & 0.1265 \\
\hline $61-75$ & 176.7 & 148.3 & 183.3 & 203.3 & 190.0 & 18.150 & 0.3263 \\
\hline $76-90$ & 180.0 & 17.00 & 182.5 & 215.8 & 181.7 & 19.622 & 0.6060 \\
\hline Total period & 178.9 & 171.1 & 207.2 & 231.9 & 198.2 & 16.453 & 0.1252 \\
\hline \multicolumn{8}{|c|}{ Feed conversation } \\
\hline $1-15$ & 5.55 & 7.17 & 4.96 & 4.84 & 5.04 & 1.092 & 0.5530 \\
\hline $16-30$ & 6.74 & 8.29 & 9.07 & 7.77 & 8.11 & 1.666 & 0.9004 \\
\hline $31-45$ & 8.33 & 7.88 & 7.98 & 5.85 & 8.49 & 0.964 & 0.3442 \\
\hline $46-60$ & 8.02 & 8.58 & 5.84 & 5.98 & 6.63 & 1.010 & 0.2562 \\
\hline $61-75$ & 8.39 & 9.19 & 8.07 & 8.06 & 8.22 & 0.818 & 0.8576 \\
\hline $76-90$ & 9.18 & 7.53 & 8.49 & 7.52 & 8.33 & 1.172 & 0.8299 \\
\hline Total period & 6.05 & 6.32 & 5.59 & 5.00 & 5.87 & 0.463 & 0.3712 \\
\hline
\end{tabular}

1 Five experimental rations as treatments: 1) the basal diet with soybean meal as a protein source, 2), 3), 4) and 5) the basal diets with $25,50,75$, and $100 \%$ of the soybean meal replaced with sesame meal, respectively.

The intake and nutrient digestibility in animals that were selected randomly and housed individually in metabolism crates on days 50-57 of the fattening period. There were no significant differences among treatments on DMI, ADG, and FCR at 1-15, 16-30, 31-45, 46-60, 61-79, 76-90, and for the total period of feedlotting (Table 3). The results were similar to that of Suliman \& Babiker (2007) and Hassan et al. (2013) who found no significant differences on initial and final BW, total weight gain, daily feed intake, ADG and FCR among the treatments that contained 15 and $20 \%$ SSM and $15 \%$ groundnut.

The digestibility of DM $(P=0.0156)$ and $\operatorname{EE}(P=0.0065)$ were different among treatments, but the digestibility of NDF, CP, and NFC were similar (Table 2). The digestibility of DM and EE increased in treatments that had $50: 50$ and $25: 75$ SBM to SSM. However, the lowest digestibility of DM and EE were observed when SBM or SSM was used individually (Treatments 1 and 5). This would suggest complementarity of SBM and SSM at ratios of 50/50 and 25/75 in terms of digestibility of DM and EE. Khanal \& Olson (2004) reported that in general there was an increment in DM digestibility for oil cake supplementations. However, Shirzadegan \& Jafari (2014) reported that the digestibilities of DM and OM were reduced by the inclusion of $15 \%$ SSM in diets of lactating dairy cows. Omar et al. (2002) reported that the digestibilities of CP and CF were greater in lambs fed diets containing SSM, whereas DM digestibility was not affected. Fitwi \% Tadesse (2013) reported no difference in DM, OM, and CP digestibility as the level of the SSM increased in sheep rations. Nevertheless; SSM was found to contain more NDF and had lower rumen degradability than the SBM in the present study. This might be because increased CP intake improved the rumen digestibility of DM and increased retention time of particulate matter in the lower compartment of 
digestive tract (Table 4). Similar to Fitwi \& Tadesse (2013), there was no difference in the digestibility of CP among the treatments in the current experiment. The lower DM and EE digestibility resulting from Treatments 1 and 5 compared with Treatments 2, 3 and 4 could be due to the relatively lower CP in Treatment 1 and higher NDF contents of Treatment 5. The SSM content of NDF was $48.43 \%$ of DM, and replacing SBM with SSM increased the NDF content of rations. The components of NDF, including cellulose, hemicellulose and lignin, are slowly digested in the rumen. A key factor influencing digestibility is the nature of the feed carbohydrates, because they form the most important source of energy for rumen microbes and thus, ultimately, for the host animal. This can affect microbial growth and fermentation in the rumen of sheep because of limitations in fermentable nitrogen and energy, respectively.

The rumen characteristics and digestion kinetics for the sheep that were fed with experimental ration are showed in Table 4. The rumen liquid $\mathrm{pH}$ and the rumen liquid ammoniacal nitrogen $\left(\mathrm{NH}_{3}-\mathrm{N}\right)$ values at the initial and at the end of the experiment were similar among treatments. Ruminal particulate passage rate and rumen mean retention time were similar, but the lower compartment's passage rate $(P=0.001)$, its mean retention time $(P=0.001)$, and ultimately total mean retention time $(P<0.0001)$ were significantly different among treatments.

Table 4 Rumen characteristics and digestion kinetics in lambs fed experimental rations that contained different soybean meal / sesame meal ratios

\begin{tabular}{|c|c|c|c|c|c|c|c|}
\hline Items & $\begin{array}{c}\text { Treatment } 1 \\
\text { (Control) }\end{array}$ & $\begin{array}{c}\text { Treatment } 2 \\
(25: 75)\end{array}$ & $\begin{array}{c}\text { Treatment } 3 \\
(50: 50)\end{array}$ & $\begin{array}{c}\text { Treatment } 4 \\
(25: 75)\end{array}$ & $\begin{array}{l}\text { Treatment } 5 \\
(0: 100)\end{array}$ & SEM & P-Value \\
\hline \multicolumn{8}{|c|}{ Ruminal characteristics } \\
\hline $\begin{array}{l}\mathrm{pH} \text { at start of } \\
\text { experiment }\end{array}$ & 6.36 & 6.13 & 6.34 & 6.62 & 6.34 & 0.170 & 0.4104 \\
\hline $\begin{array}{l}\mathrm{pH} \text { at end of } \\
\text { experiment }\end{array}$ & 6.02 & 6.09 & 5.81 & 5.90 & 5.97 & 0.158 & 0.7490 \\
\hline $\begin{array}{l}\mathrm{NH}_{3}-\mathrm{N} \text { at start of } \\
\text { experiment }(\mathrm{mg} / \mathrm{dL})\end{array}$ & 6.44 & 6.16 & 6.86 & 6.02 & 6.02 & 0.348 & 0.4153 \\
\hline $\begin{array}{l}\mathrm{NH}_{3}-\mathrm{N} \text { at end of } \\
\text { experiment (mg/dL) } \\
\text { Digestion kinetics }\end{array}$ & 6.44 & 6.86 & 6.30 & 6.60 & 6.26 & 0.464 & 0.0736 \\
\hline $\begin{array}{l}\text { Rumen particulate } \\
\text { passage rate }(\% / \mathrm{h})\end{array}$ & 9.95 & 9.90 & 10.00 & 9.85 & 10.05 & 0.0008 & 0.5577 \\
\hline $\begin{array}{l}\text { Rumen retention } \\
\text { time (h) }\end{array}$ & 10.05 & 10.10 & 10.00 & 10.15 & 9.95 & 0.0886 & 0.5603 \\
\hline $\begin{array}{l}\text { Lower } \\
\text { compartments } \\
\text { passage rate }(\% / h)\end{array}$ & $6.99^{\mathrm{ab}}$ & $7.00^{\mathrm{a}}$ & $7.00^{\mathrm{a}}$ & $6.99^{b}$ & $6.97^{\circ}$ & 0.0002 & 0.0010 \\
\hline $\begin{array}{l}\text { Mean retention time } \\
\text { in lower } \\
\text { compartments (h) }\end{array}$ & $14.29^{b c}$ & $14.28^{c}$ & $14.28^{c}$ & $14.30^{b}$ & $14.34^{\mathrm{a}}$ & 0.0045 & 0.0010 \\
\hline Total retention time & $40.34^{c}$ & $40.38^{c}$ & $40.36^{c}$ & $42.53^{b}$ & $43.29^{\mathrm{a}}$ & 0.0631 & $<0.0001$ \\
\hline Time delay $(\mathrm{h})$ & $16.00^{c}$ & $16.00^{c}$ & $16.08^{c}$ & $18.07^{\mathrm{b}}$ & $18.99^{\mathrm{a}}$ & 0.0702 & $<0.0001$ \\
\hline
\end{tabular}

a, b, c Row means with different superscripts differ significantly at $P<0.05$

${ }^{1}$ Five experimental rations as treatments: 1) the basal diet with soybean meal as a protein source, 2), 3), 4) and 5) the basal diets with $25,50,75$, and $100 \%$ of the soy bean meal replaced with sesame meal, respectively

Eating times, rumination time, and total chewing activity are presented in (Table 5). The rumination process is important as a means of reducing the size of feed particles and volume in the rumen, allowing more feed to be consumed. By reducing particle size and increasing surface area, the likelihood of degradation during fermentation and digestion is enhanced. However, the distribution of particle size of forages and rations had no significant difference in the current experiment (data not shown); therefore, it was expected that eating times, rumination time, and total chewing activity would have been similar among treatments. 
Table 5 Eating time, rumination, and total chewing activity in lambs fed experimental rations that contained various soybean meal/sesame meal ratios

\begin{tabular}{lccccccc}
\hline Items & $\begin{array}{c}\text { Treatment 1 } \\
\text { (Control) }\end{array}$ & $\begin{array}{c}\text { Treatment } \\
\mathbf{2 ( 2 5 : 7 5 )}\end{array}$ & $\begin{array}{c}\text { Treatment } \\
\mathbf{3 ( 5 0 : 5 0 )}\end{array}$ & $\begin{array}{c}\text { Treatment } \\
\mathbf{4 ( 2 5 : 7 5 )}\end{array}$ & $\begin{array}{c}\text { Treatment } \\
\mathbf{5 ( 0 : 1 0 0 )}\end{array}$ & SEM & P-Value \\
\hline Eating time (min/d) & 170.00 & 165.00 & 131.25 & 118.75 & 171.25 & 22.400 & 0.3536 \\
Rumination (min/d) & 440.00 & 407.50 & 358.75 & 376.25 & 427.50 & 48.259 & 0.7362 \\
Total chewing & 610.00 & 572.50 & 490.00 & 495.00 & 598.75 & 61.413 & 0.5070 \\
activity (min/d) & & & & & & &
\end{tabular}

${ }^{1}$ Five experimental rations as treatments: 1) the basal diet with soybean meal as a protein source, 2), 3), 4) and 5) the basal diets with $25,50,75$, and $100 \%$ of the soy bean meal replaced with sesame meal, respectively

The carcass yield and carcass characteristics such as slaughter weight, empty BW, hot and cold carcass weight, dressing percentage on live weight and on empty BW, total muscles, bone, fat and connective tissue (\% of carcass) were not different among experimental lambs fed various levels of SSM (Table 6). This is in agreement with Beshir (1996), Suliman \& Babiker (2007), and Hassan et al. (2013). The wholesale cuts (shoulder, legs, loin, rack, breast, neck and tail) of the experimental lambs as percentage of carcass weight showed no significant differences among the treatments. These results agreed with those reported by Beshir (1996) and Hassan et al. (2013). In addition, non-carcass components or carcass byproducts, such as the weights of skin, head, feet, liver, lungs and trachea, mesenteric fat, empty rumen and reticulum, spleen, pancreas, small intestine, large intestine, abomasums, omasum and sex organs of lambs, were not significantly different among the treatments (data not shown). These findings are in accordance with Suliman \& Babiker (2007), Beshir (1996), Hassan et al. (2013). The results of the current experiment showed that replacing SBM with SSM in fattening sheep improves intake, digestibility, and rumen condition, without reducing animal performance and carcass composition. Using SSM as an alternative protein sources in lamb feedlot diets reduced the cost while no adverse effect on intake, digestibility, performance, and carcass characteristics were observed. In addition, the ration containing 50/50 SSM/SBM had the superior effects to other treatments. Additionally, Obeidat \& Aloqaily (2010) reported that the use of sesame hull in Awassi lambs fattening diets had limited or no effect on carcass characteristics and meat quality.

Table 6 Carcass composition in lambs fed experimental rations that contained different soybean meal / sesame meal ratios

\begin{tabular}{lccccccc}
\hline Items & Treatment 1 & Treatment 2 & Treatment Treatment Treatment & \multirow{2}{*}{ SEM } & \multirow{2}{*}{ P-value } \\
\hline & (Control) & $\mathbf{( 2 5 : 7 5 )}$ & $\mathbf{3}(\mathbf{5 0 : 5 0 )}$ & $\mathbf{4}(\mathbf{2 5 : 7 5 )}$ & $\mathbf{5}(\mathbf{0 : 1 0 0}$ & & \\
\hline Slaughter weight (Kg) & & & & & & & \\
\\
Hot carcass weight (kg) & 40.400 & 39.250 & 46.100 & 44.400 & 43.500 & 1.759 & 0.1595 \\
Cold carcass weight (kg) & 19.802 & 19.405 & 23.200 & 21.650 & 21.650 & 1.229 & 0.3080 \\
Dressing on live weight (\%) & 19.340 & 18.853 & 22.830 & 20.715 & 21.133 & 1.230 & 0.2967 \\
Dressing on carcass (\%) & 50.99 & 50.56 & 49.67 & 51.24 & 50.23 & 2.113 & 0.4391 \\
Dressing on empty BW (\%) & 2.32 & 2.84 & 1.59 & 4.32 & 2.39 & 0.876 & 0.3217 \\
Total muscles (\%) & 52.13 & 51.97 & 50.48 & 53.34 & 51.42 & 2.432 & 0.7641 \\
Total bone (\%) & 58.32 & 59.12 & 59.33 & 58.98 & 58.72 & 2.432 & 0.5476 \\
Total fat (\%) & 18.32 & 18.43 & 18.02 & 18.54 & 18.76 & 0.832 & 0.3987 \\
Total connective tissue (\%) & 19.34 & 19.93 & 20.32 & 19.89 & 19.56 & 0.439 & 0.0987 \\
& 5.76 & 5.56 & 5.67 & 5.73 & 5.76 & 0.430 & 0.3298
\end{tabular}

1 Five experimental rations as treatments: 1) the basal diet with soybean meal as a protein source, 2), 3), 4) and 5) the basal diets with $25,50,75$, and $100 \%$ of the soy bean meal replaced with sesame meal, respectively

\section{Conclusion}

The results showed that the soluble and potential degradable DM and soluble protein were lower in SSM than SBM. In addition, the slowly degradable protein of the SSM was lower than the SBM. The 
coefficient of the degradation of protein was higher in SSM than SBM. Also, replacing the SSM with SBM in fattening lambs improves intake, digestibility, and rumen condition, without reduction in animal performance, chewing activity, and carcass composition.

\section{Acknowledgements}

The authors wish to thank Sari Agricultural and Natural Resources Science (SANRU) for financial support for this project. Also, the authors thank the members of the NOOR scientific cycle of Basij Asatid of SANRU for assistance in conducting this experiment.

\section{Authors' Contribution}

All authors have seen and approved the manuscript being submitted. We guarantee that the article is the authors' original work and has not received prior publication and is not under consideration for publication elsewhere.

\section{Conflict of Interest Declaration}

The authors declare that they have no competing interests.

\section{References}

AOAC, 2000. Official methods of analysis. (17th ed.). Association of Official Analytical Chemists, Inc., Arlington, Virginia, USA.

Beshir, A.A., 1996. Use of Roselle (Hibiscus sabdariffa) seeds for lambs feeding. MSc. thesis. Anim. Prod., University of Khartoum, Sudan.

FAO, 1990. Production Year Book. Guide to Food and Agriculture Organization. Rome, Italy. pp 52.

Fitwi, M., \& Tadesse, G., 2013. Effect of sesame cake supplementation on feed intake, body weight gain, feed conversion efficiency and carcass parameters in the ration of sheep fed on wheat bran and teff (Eragrostis teff) straw. Momona Ethiopian J. Sci. 5, 89-106.

Grovum, W., \& Williams, V.J., 1973. Rate of passage of digesta in sheep. 4. Passage of markers through the alimentary tract and the biological relevance of rate-constants derived from changes in concentration of markers in faeces. Br. J. Nutr. 30, 231-242.

Hassan, H.E., Elamin, K.M., Elhashmi, Y.H.A., Tameem Eldar, A.A., Elbushra, M.E., \& Mohammed, M.D., 2013. Effects of feeding different levels of sesame oil cake (Sesamum indicum L.) on performance and carcass characteristics of Sudan desert sheep. J. Anim. Sci. 3, 91-96.

Khan, M.J., Shah Jalal, M., \& Rashid M.M., 1998. Effect of replacing Til oil cake by poultry excreta on growth and nutrient utilization in growing bull calves. Asian-Aust. J. Anim. Sci. 11, 385-390.

Khanal, R.C., \& Olson, K.C., 2004. Factors affecting conjugated linoleic acid (CLA) content in milk, meat, and egg: A review. Pakistan J. Nutr. 3, 82-98.

Licitra, G., Hernandez, T.M., \& Van Soest, P.J., 1996. Standardization of procedures for nitrogen fractionation of ruminant feeds. Anim. Feed Sci. Technol. 57, 347-358.

Marghazani, I.B., Jabbar, M.A., Pasha, T.N., \& Abdullah, M., 2013. Ruminal degradability characteristics in vegetable protein sources of Pakistan. J. Anim. \& Plant Sci. 23. 1578-1582.

Njie, M., 1995. Economics assessment of feeding strategies for fattening ram lambs using sesame cake in the Gambia. In: Proceeding on agricultural science for biodiversity and sustainability in developing countries, Tune Landboskole, Denmark, pp.192-198.

NRC. 2007. Nutrient requirements of small ruminants: Sheep, goats, cervids, and New World camelids. Board on Agriculture and Natural Resources; Division on Earth and Life Studies. Pp 384.

Obeidat, B.S., \& Aloqaily, B.H., 2010. Using sesame hulls in Awassi lambs diets: Its effect on growth performance and carcass characteristics and meat quality. Small Rumin. Res. 91, 225-230.

Obeidat, B.S., \& Gharaybeh, F.F., 2011. Effect of feeding sesame hull on growth performance, nutrient digestibility, and carcass characteristics of black goat kids. Asian-Aust. J. Anim. Sci. 24, 206-213.

Obeidat, B.S., Abdullah, A.Y., Mahmoud, K.Z., Awawdeh, M.S., AL-Beitawi, N.Z., \& AL-Lataifeh, F.A., 2009. Effects of feeding sesame meal on growth performance, nutrient digestibility, and carcass characteristics of Awassi lambs. Small Rumin. Res. 82, 13-17.

Omar, A.J.M., 2002. Effect of feeding different levels of sesame oil cake on performance and digestibility of Awassi lambs. Small Rumin. Res. 46, 187-190.

Ørskov, E.R., \& McDonald, Y., 1979. The estimation of protein degradability in the rumen from determining the digestibility of feeds in the rumen. J. Agric. Sci. 92, 499-503.

Pollot. G.E., Ahmed, F.A., \& Mohammed, O.M, 1978. The effect of weaning age on the growth of Watish (Sudan desert type) lambs under feedlot condition. Um Banein livestock research Bulletin. No. 2.

SAS, 2005. Statistical Analysis Systems user's guide (edition 9.1). SAS Institute Inc., Raleigh, North Carolina, USA.

Şehu, A., Çakir, S., \& Şahin, T., 2010. Determination of rumen degradability of some oilseeds and meals using nylon bag technique. Ankara Üniv. Vet.Fak. Derg. 57, 173-178.

Shirzadegan, K., \& Jafari, M.A., 2014. The effect of different levels of sesame wastes on performance, milk composition and blood metabolites in Holstein lactating dairy cows. Inter. J. of Adv. Biol. and Biomed. Res. 2, 1296-1303.

Solomon, M., 1992. The effect of processing method of oil seed cake in Ethiopia on the nutritive value of: In-vitro nmetabolism in growing sheep feed a basal diet maize Stover, PhD. thesis, University of Bonn, Germany. 
Suliman, G.M., \& Babiker, S.A., 2007. Effect of diet-protein source on lamb fattening. Res. J. of Agric. and Biol. Sci. 3, 403-408.

Tesfay, H., 2007. Supplementation of Afar rams with graded levels of mixtures of protein and energy sources: effects on feed intake, digestibility, live weight and carcass parameters. MSc Thesis, Alemaya University of Agriculture, Ethiopia.

Uden, P., Colucci, E., Van Soest, P.J., 1980. Investigation of chromium, cerium, and cobalt as markers in digesta rate of passage studies. J. Sci. Food Agric. 31, 625-632.

Van Soest, J.P., Robertson, J.B., \& Lewis, B.A., 1991. Methods for dietary fiber, neutral detergent fiber and non-starch polysaccharides in relation to animal nutrition J. Dairy Sci. 74, 3583-3597.

Wang, Y., Jin, L., Wen, Q.N., Kopparapu, N.K., Liu, J., Liu, X.L. \& Zhang, Y.G., 2016. Rumen degradability and small intestinal digestibility of the amino acids in four protein supplements. Asian-Aust. J. Anim. Sci. 29, 241-249.

Yardımcı, M., Hesna Şahin, E., Çetingül, İ.S., Bayram, İ., Altunbaş, K., \& Şengör, E., 2008. Estimation of carcass composition and fat depots by means of subcutaneous adipocyte area and body and tail measurements in fattailed Akkaraman lambs. S. Afri. J. Anim. Sci. 38, 282-289. 